\title{
In-Service Training of Professional Librarians in College and University Libraries
}

\section{Dr. Wight is assistant librarian, Newark Pablic Library.}

$\mathrm{M}$ Òst of you will probably remember that at your meeting just two years ago on this campus there were three short statements presented on "some proposed inservice training programs." Keyes Metcalf suggested the internship with particular reference to training in administration.

Rudolf Hirsch presented the program ${ }^{2}$ developed for the University of Pennsylvania, to begin in the fall of 1947 , whereby not more than five exceptionally wellqualified graduates of accredited colleges and universities who believe their interests lie in university and research libraries, would be employed as trainees for two years.

Blanche McCrum, in her discussion, was inclined toward approval of the two previously mentioned papers, but with some reservations about Mr. Metcalf's special emphasis upon the training of administrators.

While I dislike to sound a pessimistic note, candor compels me to say that I do not see that the literature or experience have added much to our knowledge of inservice training of professional librarians since you met here two years ago. There

\footnotetext{
1 Paper presented at the Conference of Eastern College Librarians, Columbia University, Nov. $27,1948$.

${ }^{2} \mathrm{~A}$ report on this experiment is included in this issue of College and Research Libraries.
}

have been several articles in the professional literature in the past two years, such as those of Nathaniel Stewart in the A.L.A. Bulletin and Library Journal, and Phyllis Osteen's paper on in-service training of executives, but none referring exclusively to in-service training of the professional staff in libraries of institutions of higher education.

Several more general articles have argued the virtues of in-service training and made various general and specific proposals. Many of the younger librarians had contacts during World War II with the training programs of various federal agencies working with war industries or the armed services. As a result of these experiences there will undoubtedly come some valuable suggestions.

The most useful in-service training programs that have been developed for college and university libraries to date, in my opinion, are those concerned with the training of the nonprofessional staff. Such training is relatively easy and inexpensive to develop, even in a small library unit. Your supply of student assistants and other nonprofessional employees is also, I judge, relatively large. The significance of these facts is this: only by developing a relatively large and efficient nonprofessional staff can the truly professional work of the professional staff be adequately developed.

Adequate data are not available, so far 
as I know, of the proportions of the total work load in various types and sizes of college and university libraries which are professional and nonprofessional. Wilson and Tauber $^{3}$ give the percentage of the total professional staff of each of 50 university libraries. Since these figures omit the work of student assistants, the percentages reflect this fact by being high. The median for the 50 universities is 66.6 per cent of total staff in professional classifications. The highest figure is 95.3 per cent professional; the lowest, 30.5 per cent.

In the public library several careful studies of the distribution of library time among professional and nonprofessional activities indicate that typically only about one-third of staff time is spent on professional activities, while a much larger percentage of the total staff is professional. Obviously this means that professional librarians are engaged in nonprofessional work. Without having adequate data at hand, I hazard the guess that similar situations exist in many college and university libraries.

It is my firm belief that before we are ready for in-service training of professional librarians, on a large scale, we should first challenge the professional librarian with a real professional work assignment. Only when this has been done are we in a position to make a real fight for adequate professional salaries. The struggle for better professional pay would, I confidently believe, be easier if we admitted more frankly to college budget authorities that muchprobably most- of college library work is nonprofessional in nature, and at the same time convinced them that the professional work is more truly educational and worthy of pay commensurate with its importance.

Adequate pay for challenging professional work might do away with the necessity for

\footnotetext{
3 Wilson, Louis R. and Tauber, Maurice F. The University Library. Chicago, University of Chicago Press, 1945. (Table 16, p. 23r.)
}

much formal in-service training of professional librarians.

My second reservation about the possible effectiveness of a formal program of inservice training of professional librarians in colleges and universities is based upon the fact that the professional staff in most college libraries is small. The July 1948 College and Research Libraries gives statistics on this point. Obviously I am not referring to the large colleges and universities given in Group I of these statistics, where the median number of students in regular session is approximately 7,000, the faculty approximately 500 , and the full time equivalent.professional library staff 26 . In Group II, where the median enrolment in regular session is 966 and the faculty 69 , the professional library staff is four. Larger colleges in this group are Amherst and Wesleyan, and more typical ones are Bates, Bryn Mawr, Dickinson, and Wooster. It seems obvious that Group II colleges are probably better than the typical institutions of higher education among the approximately 1,600 in the country, and that a professional library staff of from two to four is not large enough to support a formal program of in-service training of professional staff.

In large colleges and universities the professional library staff may be of sufficient size to support a formal program of inservice training, and even a director of such training. Personally I would not like to attempt to organize and direct such a program, because I think it is fundamentally unsound on at least two points. First, the theory of organization and administration implies that certain specific work and staff are assigned to a specific department, with responsibility for the work delegated to a specific department head or supervisor. It seems to me logical to include in that assignment to the supervisor the responsibility for 
the efficiency and professional development of the staff in the operating unit, rather than to assign it to a training officer with a formal in-service training program.

The second difficulty is a more practical one. It involves the purely physical problem of trying to get and keep together, from the various departments, professional staff for a training program when the daily work schedules range over the hours from 8:30 a.m. to 9:30 p.m. Departments need the people to cover emergencies such as those caused by sickness. Others cannot be spared unless the time is made up in the department. Some are not scheduled to work at the hour assigned for training, and questions of time required for extra travel and overtime come up. Some are anxious for the training, while some for whom it is thought essential are indifferent. More questions arise than I would think possible. Individually each seems reasonable, but collectively they seem fantastic.

Enough of what seem to be the unfavorable prospects of a formal in-service training program organized and conducted by a single institution of higher education for its professional librarians. So that my position will not be misunderstood by this presentation thus far, it must be emphasized that $I$ have been talking exclusively about a formal program of professional training of professional librarians on the job, assuming that the initial professional education is reasonably adequate and that all professional staff will continue to grow as a result of normal job assignments, staff meetings, professional and other reading, and formal and informal contacts. It is also essential that the librarian have access to opportunities for professional growth that are availabe to other members of the faculty, such as time with pay for attendance at professional meetings (with expenses paid at least in part), scholarships and fellowships for study locally or elsewhere, time off during the day for appropriate courses in the institution, leave of absence, opportunity for serving on college curriculum and other pertinent committees, etc. Internships, second and third years of professional study, and similar methods of professional growth are also implied. All of these experiences, as well as other similar ones not mentioned, represent opportunities for professional growth. They do not, however, constitute a locally conducted program of in-service training of professional library staff. In fact, the presence of these and other opportunities argue against the necessity of most college and university libraries conducting formal in-service training programs for the professional staff.

Earlier I have said that challenging professional jobs and adequate pay would do away with much of the necessity for locally conducted in-service training programs for professional librarians. Responsibility for pressing for these rests primarily with the head librarian, working through and on the president of the institution. There is another area where there seems to be an added responsibility for head librarians. It can definitely be carried out on any campus. I refer to it with some hesitation, even though buttressed by the findings of psychological research in industry, and by Lyndal Swofford's article in the April 1947 College and Research Libraries, "Mental Hygiene and the College Library." Miss Swofford discusses the presence of feelings of frustration among college librarians and recommends that we "remove as many as possible of the causes of insecurity and irritation, create an atmosphere of successful achievement and hope for the future, and promote the physical and mental well-being of the individual" $(p, 166)$. The much publicized Hawthorne experiments of the Western Electric Company indicated that 
production is best when workers feel that their work is important, when they are given a chance to express their preferences and opinions, and when they feel themselves free from overly strict supervision. ${ }^{4}$

Morale is an area about which relatively little scientific knowledge is available. However the modern college librarian cannot afford to overlook this factor because of its effect upon the staff and its services. The difference between the professional problem of a librarian and the problem of a professional librarian may be tremendous. But since the problem may prevent effective work by the professional librarian, there should certainly be recognition of its importance and provision of some channel in the college library or on its campus to which even the professional librarian may turn.

In the induction program of a new professional staff member there should be definite provision for establishing friendly personal and professional relations with the appropriate college administrative officers, the instructional and the library staff, and the community. This "personnel point of view" does not represent an in-service program, but it might conceivably do something to reduce professional problems and to improve professional work.

This is rather late to define the most important phrase in the title of my paper, but quoting the generally accepted definition of in-service training may be pertinent as I begin to close. It is "management's process of aiding employees to gain effectiveness in their present and future work assignments by providing, planning, and organizing a program of systematic instruction and practice on the job. ...",

On the basis of that definition I would say that the library with which I am con-

4 Quoted from Ryan, Thomas A., Work and effort. N.Y., Ronald Press, 1947 (p.181).

sucker, W. H. "In-service training in large public libraries."' Unpublished master's paper, Graduate Li. brary School, University of Chicago, I94I. nected has no program of in-service training of professional staff. Yet many of our staff are engaged in some in-service training activities. Among those of the past three years are: a training course for discussion leaders in the great books program, professional forum, staff-edited monthly publication, talks at professional meetings, time off for attending library school and other classes, time off for teaching, partial scholarships for library school study, minor research studies of a specific function, such as reference, a general study of time and work units, and a course offered in the library by a Rutgers faculty member on techniques of leading discussion groups. These are specific in-service training activities organized to meet specific needs. They do not comprise a systematic program of in-service training, but are typical of some of the activities of a reasonably alert staff, attempting to increase its professional effectiveness.

Francis St. John, in his paper "In-service Training," read at the Library Institute of the University of Chicago in 1945, wisely recognized that the type of in-service training program developed by the Training within Industry group during World War II "is not satisfactory for training for professional library functions." $\mathrm{He}$ recommended the correspondence course and the discussion group as a basis for in-service training of the professional group, and suggested that the American Library Association might undertake the preparation of a series of weekly bulletins. "As these bulletins are received by the library, a weekly discussion group of staff members would be held."

Obviously, a group of professional librarians would not be found from a single small college library. Weekly meetings on a state or regional basis would be difficult to arrange. 
As an alternative suggestion I would propose that professional meetings such as the one now being held, those of the state library associations, and of the A.L.A. and its divisions, such as A.C.R.L., be held more nearly on the basis of an institute on in-service training. Briefly, this would mean that instead of assembling to listen to the reading of papers, the papers would be published and circulated to those registered for the meeting, approximately one month ahead of the scheduled meeting date. The meeting would then be devoted to specific discussion of the points, if any, presented in the papers, and to consideration of contrary or divergent points of view. More specifically, group experience pertinent to the topic for consideration would be brought directly to bear on the problem. For those who have real problems on their hands, proposals developed in advance might be presented for criticism.

This means to me that the typical professional conference would become to some extent a cooperative in-service training activity. Those who have no professional problems would have more time to visit and enjoy the social features of the meeting. Those who have professional problems and take them seriously would probably remain at home and work on their problems, unless the papers presented in advance carried some definite prospects of help.

In summary, it is my belief that given reasonably adequate general and professional education, a stimulating professional job with adequate pay, working and living conditions that promote high morale, and access to the types of intellectual stimulation that are common in good colleges, the professional librarian will continue professional growth without the necessity of a systematic program of in-service training. Finally, if there were a genuine and general - need for in-service training of professional staff in college and university libraries for some new activity or program, a professional meeting such as this might well comsider some revision of its type of program to make it more effective as an inservice training activity.

\section{Drexel Has New Master's Program}

The Drexel Institute of Technology School of Library Science announces that beginning with the fall term of 1949 it will offer a new curriculum leading to the degree of Master of Science in Library Science. This program will supplant the present one-year course recognized by the Bachelor's degree.

The School will grant three full tuition scholarships for the academic year 1949-50. Applicants for these scholarships must be graduates of accredited colleges or universities.

Application should be made to the Dean of the School of Library Science, Drexel Institute of Technology, 32nd and Chestnut Streets, Philadelphia 4, Pa., before April 15 , I949. 